\title{
ASPEK ISLAM DALAM TURISME KOLONIAL DI JAWA
}

\author{
Achmad Sunjayadi
}

\begin{abstract}
Despite some vital and interwoven cultural elements of the colonial Dutch East-Indies, the existence of Islam has never been brought up as part of the local culture. Since Islam in the colony was perceived with prejudice, the colonial government considered that it was not important to mark the contribution of Islam in the culture of the Indies. The paper reveals that there has been little information published by the colonial travel bureau on the Islamic spiritual aspects, despite the fact that there were some records written by foreign tourists who were interested in the practice of Islam. The tourist bureau favored Islamic architecture and featured the Hindu influence on Islam.
\end{abstract}

\section{Keywords}

An aspect of Islam, colonial tourism, Java.

\section{PENDAHULUAN}

Dalam turisme kolonial, khususnya masa Hindia-Belanda, aspek Islam hampir tak pernah atau bahkan sama sekali tidak disinggung. Kalaupun disinggung tidak banyak hal yang disampaikan. Padahal Islam telah ada di Nusantara sejak lama. Di samping itu jumlah penganutnya juga banyak.

Terlepas dari hal tersebut, ada hal yang menarik yaitu meskipun pengaruh Islam telah begitu lama dan begitu luas sebarannya di bumi Nusantara ini, namun tidak membuat Islam dipandang penting dalam konstruksi Negara Indonesia modern. Dalam buku-buku sejarah baik yang resmi (yang digunakan di sekolah-sekolah) maupun tidak resmi (bacaan umum), Islam diposisikan sebagai sesuatu yang tidak penting. Bahkan, ada kesan peranan Islam dalam mempersatukan ikatan emosional dan perjuangan serta pembentukan wilayah kepulauan 'menjadi Indonesia' pun hendak diabaikan (Hidayat 2006, xvi).

Aspek Islam dalam turisme kolonial menarik untuk diteliti mengingat seperti telah disinggung di atas, agama Islam tersebar di Asia Tenggara dan Nusantara sejak 
abad ke-12 atau 13 (de Graaf 2001, 20). ${ }^{1} \quad$ Masuknya agama ini ke Nusantara tidak berlangsung sama, baik sebagai ajaran maupun unsur-unsur budaya. Proses tersebut melalui berbagai alur kedatangan, rentang waktu dan rangkaian proses sosialisasi di wilayah-wilayah penyebaran. Di Indonesia, fenomena tersebut dapat dilihat dari sebaran angka-angka tahun bukti-bukti tertua kehadiran orang atau komunitas Islam, antara lain di Leran, Gresik (1082 M), di Barus, Sumatera Utara (1206 M), Pasai, Aceh (1297 M), dan Troloyo, Mojokerto (1368). Sedangkan dari berbagai sumber naskah kuno juga diketahui proses sosialisasi Islam, seperti di Cirebon (akhir abad ke-15), Banten (awal abad ke-16), Banjarmasin (1550), Ternate (akhir abad ke-14), Kutai (1575), dan Makassar (1605/1609). Sementara itu pengukuhan kerajaan dan kesultanan Islam Nusantara berlangsung antara abad ke-15 atau akhir abad ke-14 hingga abad ke-18 M (Ambary 1998, 36-7).

Dari tahun kontak sosialisasi Islam di Nusantara terhadap penduduk Nusantara tersebut dapat diketahui, kontak sosialisasi Islam lebih awal dibandingkan kontak dengan orang Eropa yang datang kemudian. Islam pun bukan agama asli penduduk Nusantara sehingga praktek-praktek ajaran lama yang telah dianut oleh penduduknya tentu masih terselip dalam ajaran Islam.

Dalam artikel ini dibahas aspek Islam dalam turisme kolonial di Jawa. Artikel ini berupaya menjawab apakah ada aspek Islam dalam turisme kolonial di Jawa. Aspek-aspek apa saja yang muncul dalam turisme kolonial di Jawa. Sebagai sumber digunakan buku catatan para pelancong asing di Jawa (kurun waktu 1800-1900-an). Selain itu digunakan pula buku panduan pariwisata masa Hindia-Belanda sebagai perbandingan antara turisme yang belum diatur dan telah diatur oleh pemerintah Hindia-Belanda. Untuk menjawab pertanyaan yang diajukan maka di sini digunakan pendekatan eksplanasi naratif dan pendekatan representasi 'orientalisme' dari Edward. W. Said.

\section{ISLAM DALAM PANDANGAN KOLONIAL}

Pada masa kolonial, baik VOC maupun Hindia-Belanda, hubungan antara Islam dan pemerintah kolonial (Belanda), dilukiskan oleh Karel Steenbrink seperti "kawan dalam pertikaian". Maksudnya adalah di satu sisi Islam dijadikan kawan oleh pemerintah kolonial dan di sisi lain dijadikan lawan atau musuh yang harus diperangi.

Mispersepsi, antipati, dan konflik Barat (baca: Belanda) terhadap Islam, seperti yang dikemukakan Steenbrink pada intinya terdiri dari tiga tingkatan: teologis, ekonomispolitis, dan kultural. Pada masa-masa awal kedatangan Belanda di Nusantara, konflik teologis dan ekonomis-politis sangat mendominasi (Steenbrink 1995, xxv).

Frederik de Houtman (1571-1627) dan Jan Pieterszoon Coen (1587-1629) dapat

\footnotetext{
${ }^{1}$ Pada umumnya dipercayai ada dua gelombang kedatangan Islam di Nusantara yaitu gelombang pertama pada abad ke-7 dan 8. Pada gelombang ini Islam dibawa dan disebarkan langsung oleh pedagang Arab. Gelombang kedua pada abad ke-13 penyebaran Islam mengalami akselerasi.
} 
dikatakan sebagai tokoh-tokoh penting dalam konflik ekonomis-politis. Keduanya lebih mementingkan aspek ekonomis-politis dibandingkan teologis. Hal itu misalnya dapat dilihat dari pernyataan Coen dalam memorandumnya 1 Januari 1614:

"Akankah kita berusaha mengkristenkan orang-orang Ternate atau mengambil dari mereka apa yang sebenarnya milik kita -meski dengan kekerasan, jika memang diperlukan? ...Saya mengatakan bahwa orang-orang Maluku dengan agama yang sekarang tentu saja harus dibiarkan. Kita harus mempertahankan hak kita untuk mengekspor cengkeh-walau dengan kekerasan -namun mengenai hal-hal lain kita akan banyak menutup mata."(Steenbrink 1995, 80)

Hal ini menjelaskan bahwa dalam ribuan halaman laporan dan catatan yang ia kirimkan pada de Heren XVII, Coen hampir tidak menjelaskan pandangannya terhadap Islam. Bahkan, seperti dikutip Steenbrink, Coen terlihat cenderung membiarkan penduduk Muslim setempat dalam agama mereka.

Sebaliknya mispersepsi, prasangka, dan antipati terhadap Islam dan kaum Muslim di Nusantara pada masa kolonial justru lebih kuat di kalangan para spesialis, baik teolog maupun pendeta, misalnya pendeta Francois Valentijn (1666-1727). Pada tingkat teologis ini, mereka menyerang Al Quran dan Nabi Muhammad. Sebaliknya mereka mengemukakan berbagai argumen tentang kebenaran Perjanjian Lama dan Perjanjian Baru serta Yesus Kristus. Valentijn melukiskan Islam sebagai:

“...gado-gado...[diambil] sebagian dari sumber murni Perjanjian Lama dan Baru dan sebagian dari tumpukan kotoran agama Yahudi dan agama kuno Sabaean dan Saracen. Semua ini ditambal sulam menjadi satu dengan bodoh dan kasar. Sehingga ada kesempatan yang luas untuk mempertanyakan bagaimana mungkin bahwa bangsa yang sangat banyak (dan juga luas), termasuk beberapa bangsa yang sangat cerdas, akan mengikuti kesalahan yang tidak berdasar dan agama yang tidak dapat disetujui semacam ini. Penyusun dan pendiri agama besar ini adalah Muhammad." (Steenbrink 1995, 49)

Menariknya meskipun Valentijn memandang Islam sebagai agama yang salah namun ia menganggap Islam sebagai agama terhormat. Bahkan ia memuji Muslimin yang sangat setia pada agamanya serta praktik pensucian dan pembersihan sebelum sembahyang (wudhu). Sementara itu mengenai puasa di bulan Ramadhan, ia memandangnya sebagai hal yang aneh. Menurutnya orang-orang itu terus-menerus berpuasa sepanjang hari, namun hanya sampai terbenam matahari. Mengenai puasa Valentijn berkomentar:

"Saya lebih suka menyebut itu makan dan minum secukupnya; kalau kebiasaan ini disebut puasa maka kami pun berpuasa sepanjang malam." (Steenbrink 1995, 48)

Sebagian data mengenai Islam dan Muslim di Jawa (Tengah) dapat dilihat dalam kesan Rijkloff van Goens (1619-1682) yang pernah lima kali menjadi utusan ke keraton Mataram. Laporan yang ia berikan sehubungan dengan Muslim sebenarnya hanya satu isu yaitu usahanya memperjuangkan agar para tawanan perang dibebaskan dan dapat membawa anak mereka yang dilahirkan oleh perempuan Jawa semasa mereka dihukum 
penjara, ikut ke Batavia. Van Goens juga memberikan gambaran umumnya tentang pengalaman di daerah-daerah pedalaman Jawa dan membandingkan antara cerita-cerita dan adat istiadat pra-Islam dan sesudah Islam. Ia menggambarkan:

"Dengan kedatangan Islam sebagian besar penduduk pun menggunakan tulisan Arab yang baru saja dipelajari oleh orang Melayu, bersama sekte yang terkutuk, sekitar 100 tahun silam dari orang-orang Arab dan pengikut Muhammad yang, melalui perdagangan dan seringnya mereka berhubungan dengan penduduk pulau tersebut, menanamkan pengaruhnya melalui cara tulisan dan sekaligus menyebarkan agama mereka. Sebelumnya tidak seorang pun dari penduduk itu yang pandai menulis." (Steenbrink $1995,44)^{2}$

Ketika Inggris memegang kekuasaan penuh di Hindia (1811-1814), pada masa kepemimpinan Raffles, mereka tidak menganut kebijakan pro Islam dalam bidang politik. Raffles memang tertarik pada budaya Jawa namun ia memandang para pemimpin Muslim, terutama para haji yang telah menunaikan ibadah haji ke Mekkah sebagai musuh paling besar bagi pemerintah. Dalam History of Java Raffles menulis:

\begin{abstract}
"Setiap orang Arab dari Mekkah, begitu pula orang Jawa yang kembali menunaikan ibadah haji di sana, diterima sebagai orang suci di Jawa, dan sikap cepat percaya dari kalangan orang awam sudah sedemikian rupa sehingga mereka sangat sering menghubungkan berbagai kekuatan supranatural (gaib) kepada pribadi-pribadi yang demikian. Dengan demikian tidak sulit bagi mereka membangkitkan negeri untuk memberontak. Para ulama pengikut Muhammad hampir tanpa terkecuali ditemukan paling aktif dalam setiap pemberontakan. Banyak dari mereka, umumnya keturunan campuran Arab dan orang pribumi, pindah dari satu negeri ke negeri lain di pulau-pulau bagian Timur dan umumnya karena intrik-intrik dan desakan merekalah para pemimpin pribumi terhasut untuk menyerang atau membunuh orang-orang Eropa, sebagai orang kafir dan pengacau." (Steenbrink 1995, 99)3
\end{abstract}

Menjelang akhir abad ke-19, yang dikenal sebagai puncak kejayaan kolonialisme Eropa di dunia muslim, konflik berada pada tingkatan kultural. Para ahli kolonial yang memiliki peranan penting seperti Karel Frederik Holle (1829-1896), Christiaan Snouck Hurgronje (1857-1936), Godard Arend Hazeu (1870-1929).

Ketiga tokoh tersebut adalah para pejabat penting pemerintah Hindia-Belanda dan juga sebagai Adviseur voor Inlandsche Zaken (Penasihat untuk Urusan Pribumi). ${ }^{4}$ Ketiganya melihat bahwa domestikasi terhadap Islam dan kaum Muslim akan lebih berhasil melalui pendekatan kultural daripada teologis. Mereka mempunyai pengaruh

\footnotetext{
${ }^{2}$ Rijklof van Goens, Javaense Reyse. De Bezoeken van een VOC-gezant aan het hof van Mataram 1648-1654. Amsterdam: Terra Incognita. 1995.

${ }^{3}$ Karel Steenbrink, Beberapa Aspek tentang Islam di Indonesia Abad ke-19, Jakarta: Bulan Bintang, 1984, 235 mengutip T.S Raffles, The History of Java, Kuala Lumpur: Oxford University, 1978 [cetakan pertama 1817]. Pada masa Gubernur Jenderal Daendels ada peraturan bahwa para haji - menurut istilah Daendels 'Pastor Islam' atau Mohamadansche priesters - harus memakai pas jalan jika mereka hendak pergi dari satu tempat di Jawa ke tempat lainnya. Alasan peraturan ini adalah untuk 'keamanan dan ketertiban'. Lihat J. Vredenberg "The Haddj Some of its features and functions in Indonesia", BKI 118, 1962, 91-154.

${ }^{4}$ Pembahasan mengenai peranan kantor ini dapat dilihat dalam Aqib Suminto, Politik Islam Hindia Belanda, Jakarta: LP3ES. 1985.
} 
besar terhadap kebijakan pemerintah Hindia-Belanda terhadap Islam. Kegiatan dan tulisan mereka mencerminkan aspek-aspek dasar dari perubahan sikap terhadap Muslim (Steenbrink 1995, 105). Apa yang disebut Barat sebagai 'fanatisme Islam' hanya dapat dilenyapkan melalui 'asosiasi kultural' yang pada dasarnya adalah 'pembelandaan' atau 'pembaratan' kaum Muslim.

Konsep representasi Edward Said dalam Orientalism (1991) menyebutkan adanya pikiran bahwa 'Timur' berbeda dengan di 'Barat'. Wilayah 'Timur' oleh 'Barat' dianggap wilayah yang jauh, eksotik, feminin serta penuh kenangan dan imaji. Pandangan 'Timur' merupakan sesuatu 'yang lain' daripada 'Barat' kiranya sesuai diterapkan di sini. Pandangan Barat mengenai Islam di Hindia-Belanda dapat dimasukkan dalam kategori tersebut. Dalam penelitian ini pandangan tersebut diwakili oleh pendapat para pelancong yang berkunjung ke Jawa.

\section{ISLAM MENURUT PARA PELANCONG DI JAWA}

Para pelancong yang datang ke Jawa, baik yang datang atas kemauan sendiri maupun karena alasan pekerjaan, tentunya memiliki kesan, pandangan atau stereotipe sendiri terhadap berbagai hal. Mulai dari masyarakat, adat-istiadat, budaya dan agamanya. Salah satu kesan mereka rupanya adalah Islam.

Kesan mereka itu mungkin berasal dari buku-buku yang ditulis oleh orang yang sebelumnya pernah mengadakan kontak dengan Islam atau melihat sendiri secara langsung. Citra yang tertanam dalam diri mereka kemudian bercampur dengan pengalaman mereka sendiri. Kesan itu lalu mereka tulis dan dipergunakan oleh mereka yang kelak berkunjung ke Jawa sebagai pelancong.

Berikut kesan dari beberapa pelancong yang terekam dalam beberapa buku catatan perjalanan mereka ketika mengunjungi Jawa.

J. Oliver Jz adalah seorang pegawai Algemene Secretarie sampai jenjang commies di Batavia pada 1821 dan pernah menjadi anggota Raad van Indië (Dewan Hindia) di bawah pimpinan H.W. Muntinghe. Pada 1823 ia dipecat dari Algemene Secretarie karena kecanduan pada alkohol. Ia sempat kembali ke negara asalnya lalu kembali ke Hindia menjadi penerjemah bahasa Inggris di Batavia pada 1840 dan menjadi kepala sekolah Gouvernements Eerste Lagere School (Sekolah dasar pemerintah) di Weltevreden. Lalu ia diangkat menjadi direktur Lands Drukkerij dan redaksi Javansche Courant (Olivier 2001, vi-viii).

Sebagai salah seorang pegawai pemerintah ia menuturkan aspek Islam dari berbagai segi. Catatan perjalanannya ini menggambarkan situasi di Jawa pada tahun 1800-an. Pertama, ia menjelaskan kewajiban yang harus dilakukan seorang Islam yaitu menjalankan ibadah di bulan Ramazan [Ramadhan], dikhitan serta pergi menunaikan ibadah haji ke Mekkah (Olivier 2001, 173-4). Olivier juga menuliskan kesan mengenai poligami yang diperkenankan dalam ajaran Islam. Namun, ia menambahkan poligami 
hanya dilakukan oleh:

"...de aanzienlijkste en vermogendste inlanders de wet van Mohamed betrekkelijk het huwelijk, in hare geheele uitgestrekte te baat genomen."

(penduduk pribumi yang terkaya dan terpandang yang memanfaatkan hukum dari Muhammad mengenai menikah) (Olivier 2001, 175).

Ia lalu memberikan contoh hanya para raja dan beberapa orang kaya yang memiliki empat istri sah (vier wettige vrouwen), selain sejumlah goendik atau nyai. Sedangkan para kepala kampung sekurangnya memiliki dua istri atau paling banyak tiga istri (Olivier 2001, 175).

Hal yang serupa juga diungkapkan oleh Augusta de Wit, seorang guru dan wartawan dari Belanda yang mengunjungi Jawa akhir 1890-an. Dalam bukunya Java: Feiten en Fantasieën (Java :Fact en Fancies) ia menuliskan bahwa penduduk Jawa menjalankan perintah dalam Islam seperti bersyahadat, shalat di messigit (mesjid), berpuasa di bulan Ramadhan, pergi ke Mekkah untuk berhaji. Namun, pengaruh Hindu masih tampak jelas (Wit 1987, 221). Pengaruh Hindu yang masih kuat juga dikemukakan oleh seorang pelancong asal Inggris, Charles Walter Kinloch yang mengunjungi Jawa pada pertengahan abad ke-19. Menurutnya penduduk Jawa yang menganut Islam mengikuti ajaran Nabi Muhammad. Namun, pada prakteknya pengaruh Hindu masih melekat karena sebelumnya mereka memang menganut Hindu (Kinloch 1987, 111).

Pendapat kuatnya pengaruh ajaran sebelum Islam juga dikemukakan oleh pelancong lainnya yaitu H.W. Ponder dalam Java Pageant: Impressions of the 1930's. Ia mengatakan meskipun sudah menganut Islam tapi animisme masih cukup berpengaruh besar. Mereka masih percaya hantoe dan doekoen serta pawang (Ponder 1989, 113).

Louis Couperus, seorang sastrawan Belanda kelahiran Hindia yang melakukan perjalanan ke Hindia-Belanda (Sumatra, Jawa, Bali) pada 1920-an juga mempertanyakan apakah Islam memang benar-benar telah 'menguasai' Nusantara secara keseluruhan. Secara garis besar memang benar, penganut Islam sangat besar tetapi dalam jiwa masyarakat Jawa Tengah serta Jawa Timur masih tersimpan ajaran Hindu. Couperus mengaitkan bahwa ajaran Islam datang tanpa membawa seni. Sedangkan Hindu misalnya, datang dengan kesenian patungnya yang telah berakar kuat dalam masyarakat Jawa (Couperus 1992, 229).

Seorang pelancong dari Jepang Marquis Tokugawa yang juga seorang ilmuwan biologi ketika mengunjungi Jawa pada 1929 berkomentar mengenai Pulau Bali. Ia mengaitkan pengaruh Islam di Jawa pada abad ke-15 menyebabkan para penganut Hindu yang terdesak 'mengungsi' ke Bali (Tokugawa 2004, 150).

Selanjutnya adalah penggambaran mengenai tempat ibadah yaitu mesjid dan variasi berbagai sebutannya. Oliver menggambarkan misidjiet (mesjid) besar yang disebutnya sebagai Mahomedaanschen tempel (kuil atau tempat beribadah pengikut Muhammad) yang terletak di sebelah beberapa pohon beringin di sekitar Surabaya 
(Olivier 2001, 239). Gambaran mesjid juga diberikan oleh Justus van Maurik, seorang pengusaha cerutu asal Amsterdam yang berkunjung ke Jawa pada 1800-an. Ketika itu ia sedang mengunjungi Bandung dan tinggal di sekitar rumah residen, dekat alun-alun. Maurik menyebutnya missigit (Maurik 1897, 232).

Lain halnya dengan Eliza R. Scidmore seorang pelancong asal Amerika yang bertugas untuk National Geographic akhir 1890-an mengunjungi Jawa. Ia menyebutkan para pengikut orang yang 'berhidung mancung' dan pengikut Nabi (Muhammad) tersebut masuk ke Nusantara pada abad ke-15 mendirikan messigit atau mesjid mereka di setiap daerah. Ia menggambarkan sebuah messigit di Batavia yang dibangun dengan ubin berwarna putih kebiru-biruan sehingga tampak sejuk di mata. Di depan pintunya berjejer bakiak kayu dan sepatu kulit. Para jemaahnya yang bersurban di kepalanya bersujud menghadap mihrab yang berada di posisi ke arah barat laut/Mekkah (Scidmore 1984, 37-8).

Kesan mengenai mesjid juga digambarkan oleh seorang prajurit tanpa nama yang catatannya diterbitkan oleh H.C.C. Brousson di Bandera Wolanda edisi 1910-1912. Prajurit itu mengunjungi mesjid di Luar Batang. Ia menggambarkannya sebagai sebuah bangunan terbuka dan tampak beberapa haji sedang beribadah. Ia pun yang diantar oleh rekannya sempat masuk ke dalam mesjid setelah melepaskan sepatu mereka. Tempat 'kramat' tulisnya merupakan tempat yang paling dihormati di Hindia. Di luar mesjid, sebuah jalan kecil yang menuju ke arah mesjid berdiri para pengemis kotor. "Mereka berderet persis serdadu," komentar serdadu itu. Mereka lalu menyambut dirinya serentak dengan 'paduan suara': “Tuan! Minta duit tuan!”. Mengenai mesjid itu sendiri ia berkomentar:

"Mesjid atau missigit itu kelihatan rapi dan terpelihara baik. Bangunan itu memiliki lebih dari satu atap dengan tiang-tiang penyangganya yang dari luar terlihat indah."

Ia pun menuliskan kebiasaan orang-orang itu sebelum bersembahyang dengan membersihkan kepala, telapak tangan, lengan, kaki dari lutut hingga tumit di sebuah bak semen di luar mesjid (Brousson 2004, 88-9).

Selain mesjid, tempat pemakaman juga menjadi perhatian para pelancong tersebut. Oliver menggambarkan sebuah tempat pemakaman yang dikelilingi dinding batu. Makam-makam itu mengikuti cara Islam (Mahomedaansche wijze). Makam-makam itu diberi tanda dari batu, batoe-bintang yang terbuat dari marmer putih yang cukup banyak tersedia di sana. Pada batu itu terdapat tulisan Arab (Olivier 2001, 243).

Jan Poortenaar seorang seniman yang melakukan perjalanan bersama keluarganya ke Jawa, Bali, Sulawesi, Kalimantan dan Sumatra pada tahun 1920-an mengungkapkan pengalamannya ketika berkunjung ke Makam Sunan Gunung Jati di Cirebon. Ketika mereka tiba di sana, mereka dikerubuti oleh para pengemis tua dan anak-anak. Ke mana pun mereka pergi selalu dibuntuti oleh para pengemis itu. Pada sisi yang lain, ia melihat serombongan haji yang sedang berdoa di makam tersebut (Poortenaar 1989, 45-6). 
Sedangkan Couperus menyebutkan makam di Gresik yang merupakan makam keramat dari Hadji Poerwa, Malik Ibrahim dan Magfoer. Ia menggambarkan nisan pada makam itu penuh hiasan yang diduga berasal dari masa Majapahit dan bukan seni Islam (Couperus 1992, 230). ${ }^{5}$

Upacara yang dipraktekkan oleh masyarakat juga tak luput dari perhatian para pelancong tersebut. Misalnya secara khusus, Oliver mengamati upacara sedekahan yang ia gambarkan:

"Para pria duduk bersila saling berhadapan. Di hadapan mereka masing-masing ada sebuah pinggan penuh makanan. Di belakang para pria itu duduk kaum perempuan dan anak-anak. Makanan yang dihidangkan berupa ayam jago, daging sapi, ikan bendong [bandeng?], telur yang menumpuk di pinggan. Tak ada yang bersuara atau bergerak, hanya ada satu orang yang bergerak yaitu toekang-itoeng. Ia berkeliling sambil menghitung jumlah kepala yang hadir untuk menentukan jumlah porsi makanan yang disediakan. Setelah toekang-itoeng beraksi, orang yang bergerak lainnya adalah priester (sang pemimpin doa).Ia membakar dupa lalu mengucapkan doa dalam bahasa Arab yang diikuti oleh para penduduk dengan kata "amin". Acara sedekah ini diakhiri dengan makan bersama." (Olivier 2001, 245-6)

De Wit memberikan komentarnya mengenai upacara sedekah yang memberikan sesajian bunga, buah-buahan yang ditujukan bagi dewata dan para leluhur. Menurutnya, upacara ini merupakan pengaruh Hindu yang masih kuat di kalangan penduduk (Wit 1987, 278).

Sehubungan dengan upacara tersebut H.W Ponder mengungkapkan hampir semua peristiwa dalam kehidupan manusia (Jawa) perlu diupacarakan. Misalnya kelahiran Nabi (Muhammad), kehamilan, kelahiran, pernikahan dan kematian. Bahkan bangunan rumah, jembatan, saat akhir bulan puasa hingga ketika salah seorang pegawai Eropa akan pulang ke negerinya juga perlu diupacarakan. Tujuannya adalah untuk menghindari hal-hal buruk dan roh jahat (Ponder 1990, 86)

Mengenai upacara perkawinan, Couperus menceritakan upacara perkawinan salah seorang puteri bangsawan di Solo. Selain upacara secara adat Jawa, perkawinan itu menggunakan cara Islam. Calon pengantin pria dinikahkan oleh Penghoeloe atau Tafsir Anom yang oleh Couperus disebut sebagai priester. Lalu penghulu itu bertanya pada calon pengantin pria:

"Namens haar vader bied ik de bruid u. Neemt ge haar aan?" (Atas nama ayahanda pengantin putri saya nikahkan Anda dengannya. Apakah Anda mau menerimanya?"

Pengantin pria lalu menjawab: "engeh (Inggih)!". Jawaban ini pula yang diberikan oleh pengantin pria untuk pertanyaan-pertanyaan lainnya. Penghulu lalu mengutip beberapa ayat dari Qur'an (Couperus 1992, 191).

Istilah penghulu di sini mengacu pada nama jabatan keagamaan Islam di Jawa, baik

\footnotetext{
${ }^{5}$ Makam itu dihiasi marmer yang berasal dari Gujarat, Cambay yang bertuliskan huruf kufi. Pola hiasan pahatnya sama dengan beberapa makam yang ada di Pasai. Lihat Hasan Muarif Ambary, op.cit., 70
} 
di lingkungan kerajaan yang swapraja, maupun di kabupaten-kabupaten yang dikuasai oleh pemerintah kolonial. Pemerintah kolonial memberikan perhatian yang tinggi kepada penghulu karena penghulu merupakan jabatan keagamaan pribumi yang mempunyai pengaruh kuat terhadap pelaksanaan agama Islam dan hukum Islam pada masyarakat pribumi. Penghulu di Jawa memiliki makna berbeda dengan penghulu di dunia Melayu. Penghulu di dunia Melayu memiliki makna 'yang berada di atas' atau 'pemimpin'. Di Sumatra Barat, penghulu adalah kepala nagari dan di Riau setingkat dengan kepala desa. Di Jawa, penghulu dalam kedudukannya itu mempunyai otoritas yang penuh dalam semua urusan kepemerintahan yang berhubungan dengan agama Islam, terutama dalam pelaksanaan hukum syariah, dan sebagai kepala masjid yang mencakupi tugas-tugas memimpin ibadah dan pembinaan umat serta pendidikan agama (Hisyam 2005, 126).

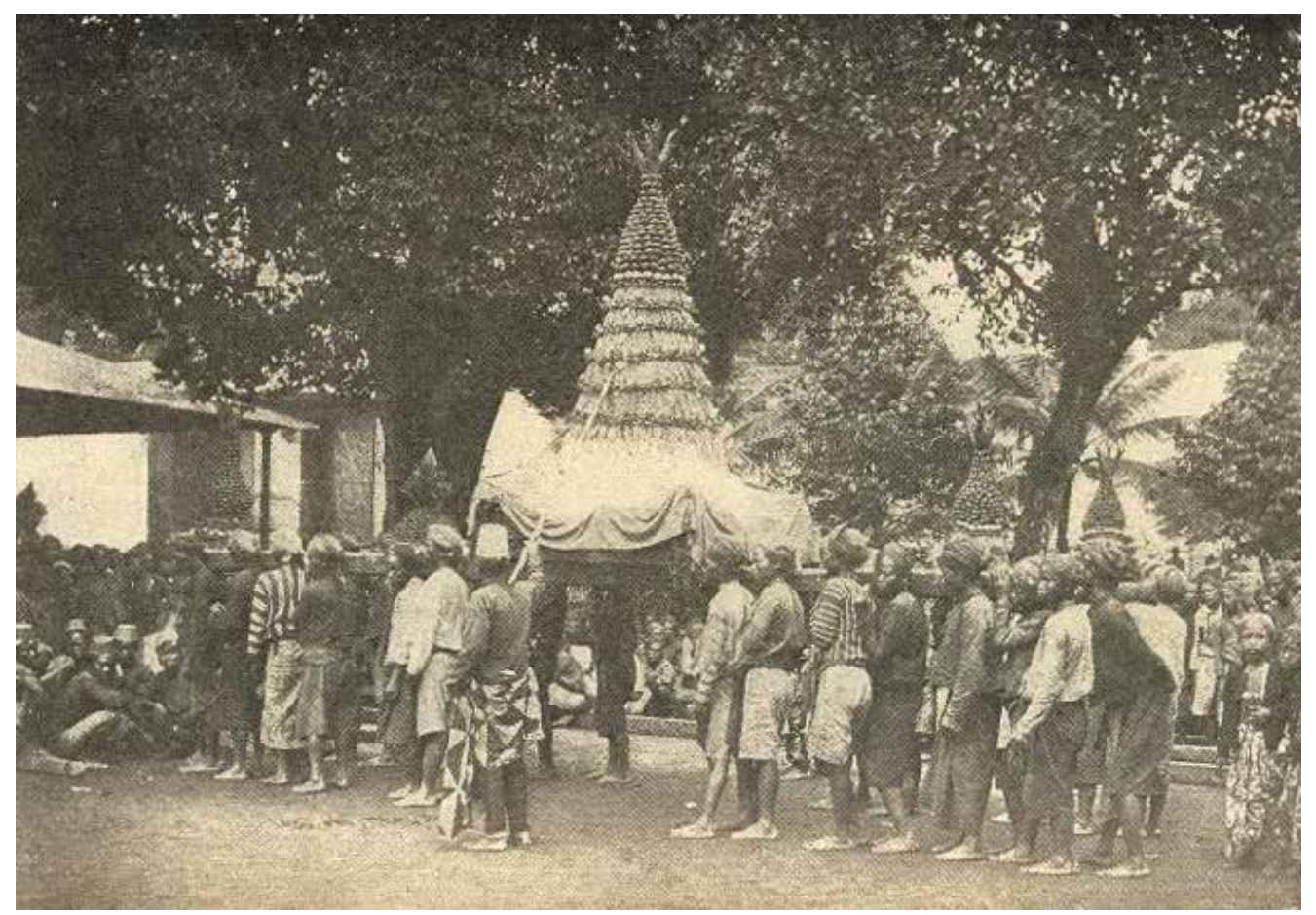

Gunungan (Maulid Nabi Muhammad) (Augusta de Wit 1905)

Khusus mengenai kelahiran nabi Muhammad yang jatuh pada 12 Rabiul Awal, Ponder menceritakan penyelenggaraan Garebeg Moeloed serta tahun baru Islam/Hijriah (Ponder 1990, 87).

Hal menarik lainnya adalah situasi hari raya Idul Fitri (Lebaran) yang digambarkan oleh Ponder sebagai berikut:

"Lebaran adalah peristiwa yang penuh kegembiraan dari semua peristiwa yang dapat dilihat di Jawa. Semua orang mengenakan pakaian baru. Warna-warni pakaian yang mereka kenakan seperti taman bunga di pegunungan. Kaum perempuan mengenakan sarung beraneka corak dan beraneka warna. Merah, hijau, biru, kuning. Mereka juga mengenakan badjoe yang juga beraneka warna, merah, hijau, biru, kuning serta corak bunga. Terbuat dari bahan sutera atau muslin (kain tipis untuk tirai). Beberapa gadis muda mengenakan kodoengan yang terbuat dari chiffon (kain sutera tipis) dan dibordir. Para gadis 
itu juga 'memutihkan' wajahnya dengan bedak. Mereka ada yang berpasang-pasangan, bergandengan tangan. Sementara itu kaum pria mengenakan sarung atau kain dengan baju atau kemeja dari bahan drill berwarna khaki, putih. Beberapa mengenakan sandal bahkan ada yang berjalan sambil menenteng sandal di tangannya. Kebanyakan kaum perempuan yang melakukannya." (Ponder 1990, 87)

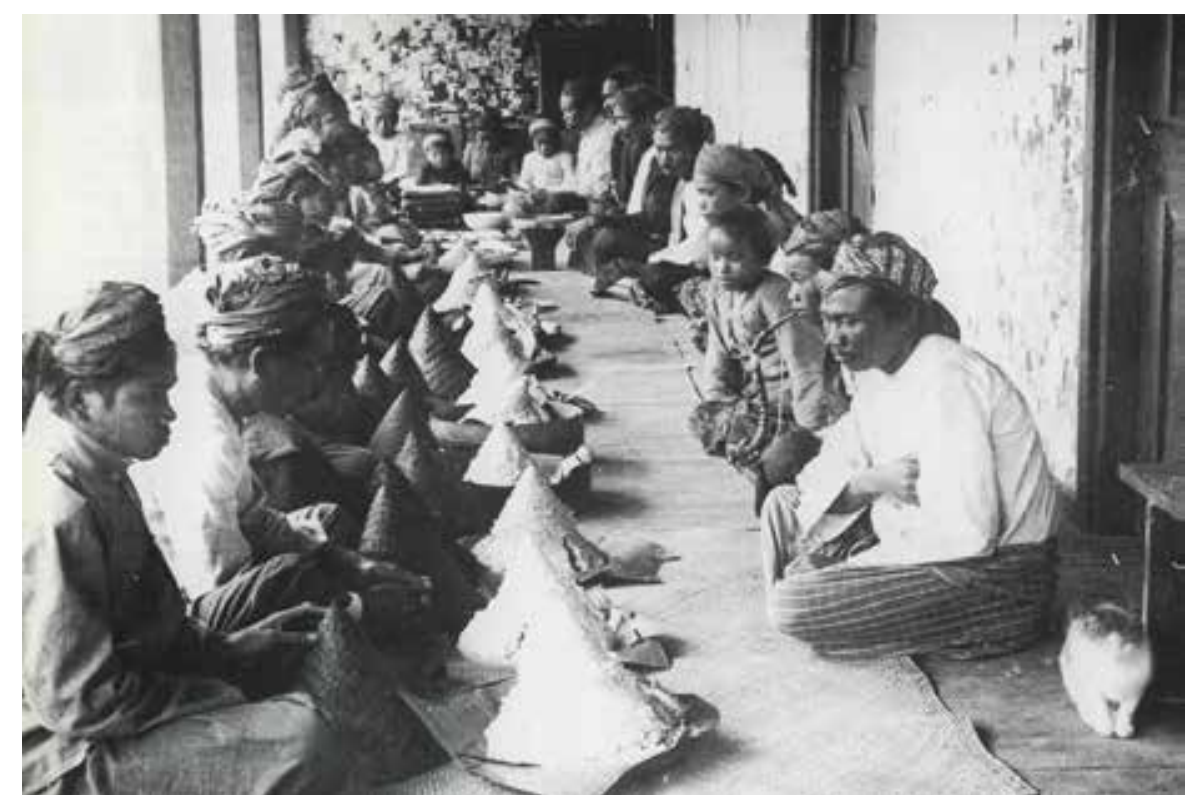

Slametan di Preanger (Cibodas) tahun 1907 (Koleksi KIT-Amsterdam)

Satu hal yang juga tak luput dari perhatian Ponder adalah kebiasaan penduduk kampung pada saat bulan puasa. Orang keliling kampung sambil membawa kentongan untuk membangunkan orang dan berteriak: "Sa-a-oe-rr". Pada saat yang sama terdengar suara bedoek dipukul dari mesigit /mesjid (Ponder 1990, 91).

Sejarah masuknya Islam di Jawa diungkapkan pula oleh Ponder. Menurut Ponder Islam dibawa oleh para pedagang Arab dan Malaka. Mereka menjadikan Gresik dan Tuban sebagai tempat persinggahan sebelum melanjutkan perjalanan ke Kepulauan Maluku untuk mencari rempah-rempah. Salah seorang pedagang itu adalah Malik Ibrahim yang wafat di Gresik pada 1419 (Ponder 1990, 93).

\section{ASPEK ISLAM DALAM TURISME KOLONIAL DI JAWA}

Gambaran, pendapat, kesan mengenai Islam yang diungkapkan oleh beberapa pelancong yang mengunjungi Jawa tentu belum dapat dikatakan mewakili pendapat para pelancong secara keseluruhan. Namun, setidaknya kita dapat menelusuri benang merah, aspek Islam apa saja yang mereka komentari. Berdasarkan kesan dan pendapat mengenai Islam dari para pelancong yang mengunjungi Jawa pada masa kolonial dapat diketahui melingkupi berbagai aspek. Misalnya bentuk bangunan mesjid, para penganut Islam, kunjungan ke makam keramat, perayaan dan upacara yang masih mendapat pengaruh budaya setempat bahkan ajarannya. Tentu hal tersebut tidak sepenuhnya tepat atau benar. Tergantung dari citra sebelumnya yang dimiliki setiap pelancong. 
Misalnya saja dalam memandang kebiasaan ziarah ke makam keramat. Kesan yang dimiliki oleh para pelancong (Barat) tentu berbeda dengan penduduk Hindia ketika mereka mengunjungi tempat tersebut. Fenomena ziarah di Jawa sendiri sudah berlangsung sejak lama. Jauh sebelum Islam masuk ke Nusantara. Kunjungan ke tempat keramat yang bersifat 'pra-Islam' sama sekali tidak berkaitan dengan Islam. Tempattempat seperti itu masih banyak di Jawa. Lalu tempat tersebut dinyatakan sebagai makam Islam agar sesuai dengan agama para pengunjung. Dengan kata lain unsur-unsur Islam dipajang secara berdampingan dengan unsur 'pra-Islam' (Chambert-Loir 2007, 357).

Makam Gunung Jati merupakan contoh situs campuran. Makam wali yang tidak diragukan kesahihan historisnya, berdampingan dengan makam-makam orang yang tidak jelas asal-usulnya, makam-makam kosong, petilasan tokoh-tokoh mitis seperti Semar dan bahkan suatu puser (tempat timbul dunia gaib). Semua itu berarti berbagai lapis kepercayaan bercampur satu sama lain. Namun, semua ritus tersebut bersifat Islam (Chambert-Loir 2007, 359).

Seperti yang telah diungkapkan pada bagian-bagian sebelumnya, pemerintah Hindia-Belanda juga memiliki cara pandang yang berbeda terhadap aspek Islam. Pemerintah Hindia-Belanda berupaya menyajikan aspek Islam tertentu yang mereka anggap dapat disajikan kepada para pelancong sesuai dengan kebijakan mereka. Misalnya dalam buku yang secara resmi dikeluarkan oleh pemerintah Hindia-Belanda, Gedenkboek voor Nederlandsch-Indie ter gelegenheid van het regeeringsjubileum van H.M. De Koningin 1898-1923, dimasukkan sejarah masuknya Islam di Nusantara. Tulisan itu berjudul De Islam. Godsdienstig en Maatschappelijk werk dengan penulisnya E. Gobee (Gedenkboek 1923, $291-6){ }^{6}$

Dalam tulisan itu diuraikan para pengajar Islam di Arab Saudi dan Muslim serta pengaruh mereka di Nusantara. Misalnya ajaran tarekat Naqsjabendijjah /Naqsyabadiyah (Gedenkboek 1923, 293), seorang modernis Islam di Jawa, Kyai Haji Ahmad Dahlan dengan organisasi Muhammadiyah di Yogyakarta, Kongres Islam pertama di Hindia pada bulan Oktober 1922 di Cirebon serta yang tak kalah pentingnya (menurut pemerintah Hindia Belanda) adalah tentang Snouck Hurgronje, peletak dasar Islampolitiek ${ }^{7}$ di Hindia (Gedenkboek 1923, 296).

\footnotetext{
${ }^{6}$ E. Gobee adalah seorang adviseur (penasihat) Inlandsche Zaken tahun 1923, 1927-1937. Suminto, op.cit., 142

7 Pada dasarnya Islampolitiek adalah memasukkan agama Islam dan hukum Islam sebagai bagian dari hukum adat, memasukkan orang-orang Arab ke dalam Vreemde Oosterlingen (Timur Asing), memberikan kebebasan bagi orang Islam di Hindia untuk memilih perlakuan hukum dan mencegah meluasnya gerakan Pan-Islamisme, termasuk 'memata-matai' (mengawasi) orang Hindia yang melakukan perjalanan menunaikan ibadah haji. Ambary, op.cit., 87.
} 


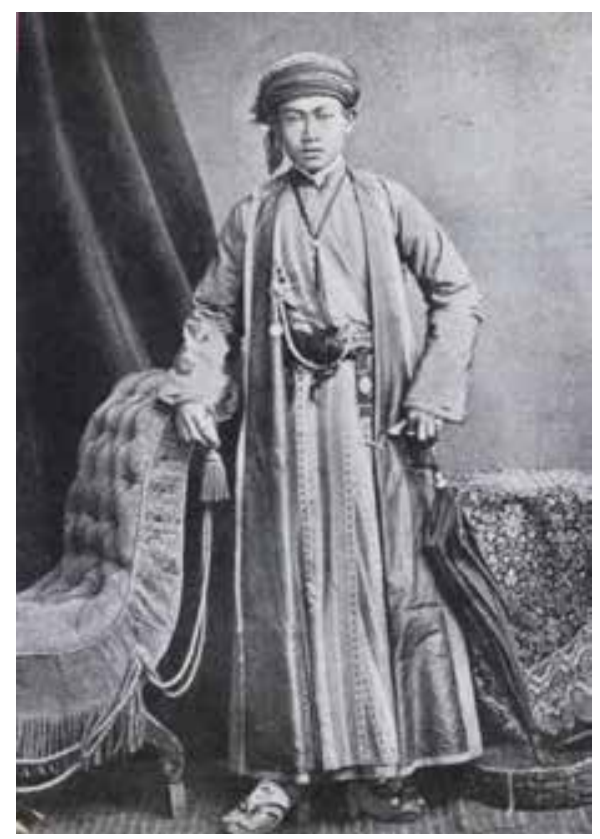

Seorang haji yang pulang dari Mekkah tahun 1916 (Tio Tek Hong- Weltevreden)

(Haks 2004, 185)

Uraian tersebut dilengkapi dengan ilustrasi foto sebuah missigit (mesjid) di Tasikmalaya (Gedenkboek 1923, 118). Foto lainnya adalah foto para haji yang baru kembali dari Mekkah dan menjalani karantina (Gedenkboek 1923, 120-1). Mengenai pakaian haji ini pernah diuraikan oleh Raffles disebut sebagai para 'pendeta' yang berpakaian serba putih dan meniru turban-turban bangsa Arab. Pakaian haji yang khas ini membuat mereka menonjol di masyarakat dan menjadi momok bagi pemerintah Hindia-Belanda karena dianggap dapat menghasut rakyat (Dijk 2005,83). ${ }^{8}$ Oleh karena itu pemerintah mengeluarkan semacam peraturan untuk "kostum Muhammad dan turban" itu. Orangorang yang kembali dari perjalanan haji harus mengikuti semacam ujian yang diadakan oleh bupati atau kepala-kepala wilayah yang setingkat. Jika lulus maka mereka akan menerima semacam sertifikat dan izin untuk berpakaian haji (Dijk 2005, 84).

Memang buku Gedenkboek (1923) tersebut secara langsung tidak dimaksudkan untuk menjadi buku panduan bagi para pelancong. Namun, gambaran dari buku resmi pemerintah tersebut dijadikan "sumber" untuk buku panduan turis, Gids voor Indië: handleiding en hotel, pension, toko en dienstengids voor new comer en toeristen in Nederlandsch Indië terbitan tahun 1933. Buku itu merupakan buku hasil kerjasama gemeenten (kotaprajakotapraja) di Hindia-Belanda, VTV, perusahaan pelayaran. Dalam buku tersebut sejarah masuknya Islam hanya disajikan satu halaman, sementara itu sejarah masa Hindu 3 halaman dan sejarah orang Belanda 3 halaman. Hal yang menarik, ilustrasi yang

8 Beberapa karya sastra Hindia-Belanda menggambarkan sosok haji sebagai sosok menakutkan dan jahat, seperti novel Stille Kracht karya Louis Couperus (1900). 
ditampilkan justru seorang pria berpakaian penari Jawa (Gids voor Indië 1933, 12).

Hal yang menarik adalah uraian masuknya sejarah masuknya Islam ke Jawa. Dalam buku panduan turis tersebut sejarah masuknya Islam di Jawa disandingkan dengan berakhirnya masa Hindu di Jawa. Hal tersebut ditandai dengan berakhirnya masa kerajaan Mataram (kuno) di Jawa Tengah dan Pajajaran di Jawa Barat (Gids voor Indië 1933, 12).

Selain itu dalam upaya mempromosikan Jawa (Hindia-Belanda), pihak pemerintah melalui Vereniging Toeristenverkeer (VTV) juga menggunakan kartu pos sebagai sarana promosi. Menariknya, pilihan gambar yang disajikan adalah gambar messigit (mesjid).

Selain gambar mesjid terdapat pula gambar perayaan Gerebek Dhal (Tahun Baru Islam/Hijriah) di keraton Yogyakarta yang berangka tahun 1909. Dalam gambar itu terlihat Sultan dan Residen dengan diiringi para pengawal lengkap dengan payung kebesaran. Di bawah kartu pos itu diberi keterangan:

“Gerebek Dhal tahoen 1909. Sultan dan Resident kaloear dari pintoe regal Keraton." (Bonnef 1994, 73).

Juru foto yang mengambil gambar itu adalah K. Cephas yang merupakan juru foto istana Yogyakarta. Foto tersebut menarik untuk dianalisa. Dalam foto tersebut tampak Sultan Yogyakarta yang berjalan berdampingan dengan Residen. Sultan Yogyakarta yang merupakan wakil Allah (kalifatullah) di dunia berdampingan dengan wakil pemerintah Hindia Belanda. Setelah Islam masuk, Raja tidak lagi dianggap sebagai perwujudan dewa, melainkan wakil Allah di dunia. Gelar baru yang disandang adalah kalifatullah (dari kata kalifah). ${ }^{9}$ Tentu adalah hal yang menarik jika wakil Allah di dunia (Sultan) berjalan berdampingan dengan wakil pemerintah Hindia-Belanda yang dapat saja menggambarkan 'penaklukan' terhadap Islam.

Dalam koleksi kartu pos lainnya, gambar yang ditampilkan hampir semua berupa tempat ibadah (mesjid). Misalnya pada kartu pos yang dicetak tahun 1908 oleh Tio Tek Hong (Weltevreden) ditampilkan gambar oude messigit (mesjid tua) Kroekoet (Haks 2004, 94). Lalu gambar missigit di Cirebon yang diterbitkan Visser \& Co /Weltevreden (Haks 2004, 124), missigit di Sukabumi diterbitkan Visser \& Co dan Manonjaya diterbitkan G.j. de Kruijff \& Co /Buitenzorg (Haks 2004, 163). Hal yang menarik adalah bentuk atap dari bangunan-bangunan mesjid tersebut yang beratap tumpang. Ada yang beratap tumpang dua dan ada yang tiga. Yang merupakan peninggalan dari masa sebelum masuknya Islam.

Dari uraian di atas kita dapat mengetahui ternyata aspek-aspek Islam juga menjadi

\footnotetext{
9 Gelar ini pertama kali dipakai oleh Amangkurat IV (1719-1724) yang lengkapnya "Prabu Mangkurat Senapati Ingalaga Ngabdu'-Rahman Sayidin Panatagama Kalipatullah" dan setelah Perjanjian Giyanti menjadi gelar yang secara tetap dipakai oleh para Sultan Yogya, termasuk Pangeran Diponegoro. Denys Lombard, Nusa Jawa: Silang Budaya, Warisan-Warisan Kerajaan Konsentris. Jakarta: Gramedia Pustaka Utama. 1996, 65.
} 
obyek pengamatan para turis. Aspek-aspek yang menjadi amatan mereka sebagian besar adalah aspek material (yang dapat dilihat). Apalagi jika obyek tersebut masih berkaitan dengan budaya sebelumnya (Hindu) yang memang menjadi obyek andalan pemerintah Hindia-Belanda.

Konsep budaya yang ditampilkan oleh pemerintah Hindia-Belanda berupa kemasan yang terbungkus rapi yang dikaitkan dengan adat. Hal ini dapat dilihat dalam entri-entri yang dimuat dalam Encylopaedie Nederlandsch Indië (ENI) 1917 Vol 1 memuat berbagai entri yang berhubungan dengan adat seperti entri adat, adatrecht, adatrechtspraak dan adatregelingen. Dalam ENI, ditegaskan bahwa adat mencakup pada kebiasaan yang mengarahkan setiap aspek kehidupan pribumi dalam hubungan sosial, pertanian, perawatan orang sakit, struktur peradilan, pemujaan leluhur, pemakaman, permainan dan hiburan rakyat (ENI 1917,6)

Seperti yang dikemukakan oleh Gouda (2007) bahwa dalam daftar ensiklopedi untuk entri adat menunjuk "kebiasaan pribumi murni", di antara orang pribumi muslim. Tradisi tersebut disamakan dengan penerapan hukum Islam (hoekoem, sarat, sjarat, oekoem). Dengan kata lain Islam yang dimaksud oleh pemerintah Hindia-Belanda lebih pada adat dan bukan religi.

\section{PENUTUP}

Bila kita melihat Islam dan turisme masa kolonial, seperti dua hal tersebut saling bertolak-belakang. Di lain pihak, pemerintah berupaya menarik minat para calon turis untuk mengunjungi Hindia. Namun, pada pihak yang lain ada satu unsur yang dalam pandangan pemerintah Hindia- Belanda dapat menghambat upaya tersebut.

Sepertinya pihak pemerintah Hindia-Belanda tidak terlalu memberikan porsi yang cukup besar kepada Islam. Hal ini dapat dilihat dari uraian informasi tentang Islam dalam buku panduan turisme yang tidak begitu lengkap dan banyak. Namun, hal yang menarik adalah para turis tersebut justru mengomentari dan memberikan kesannya terhadap Islam. Kesan mereka itu memang sedikit tercampur dengan informasi sebelumnya yang mereka terima dari buku-buku.

Pertanyaan yang muncul adalah mengapa dalam Gedenkboek tersebut hanya digambarkan sekilas masuknya Islam di Nusantara, Islam modern (Muhammadiyah), aspek material (bangunan mesjid), peran Snouck Hurgronje dalam politik Islam dan ilustrasi para haji yang dikarantina.

Kemungkinan pemerintah Hindia Belanda ingin memperlihatkan Islam di Hindia merupakan Islam yang telah mereka 'taklukkan' dan 'domestikasi'. Islam di Hindia adalah Islam yang meski modern, masih terpengaruh oleh ajaran Hindu. Sehingga para turis, khususnya turis asing diharapkan tidak perlu mengkhawatirkan keamanan mereka bila hendak berkunjung ke Jawa.

Apabila ternyata pemerintah Hindia- Belanda berupaya 'menutupi' sosok Islam 
sebenarnya di Hindia dan menampilkan Islam seperti yang mereka inginkan, dapat dikatakan upaya itu tidak sepenuhnya berhasil. Alasannya adalah aspek Islam juga menjadi perhatian para turis meskipun mereka memiliki pandangan yang berbeda.

Satu hal lain yang tidak kalah pentingnya adalah pemerintah Hindia-Belanda bukan menampilkan dan menjual nilai 'spiritual' atau religi, dalam konteks ini adalah Islam. Pemerintah Hindia-Belanda justru ingin menampilkan dan menjual nilai 'estetik' atau keindahan secara materi. Hal tersebut dapat diwakili dengan promosi melalui kartu pos yang menggunakan pilihan gambar mesjid dengan berbagai bentuk arsitekturnya serta berbagai upacara keagamaan.

\section{DAFTAR ACUAN}

Ambary, Hasan Muarif. Menemukan Peradaban: Jejak Arkeologis dan Historis Islam Indonesia. Jakarta: Logos. 1998.

Bonnef, Marcel \& Stephen Grant . "Bons baiser de Batavia, Cartes postales De Indes Neerlandaises", Archipel 47, 73. Paris: du Centre National de la Recherche Scientifique et de I'Institut National des Languages et Civilisation Orientales. 1994.

Brousson, H.C.C. Gedenkschriften van een oud koloniaal: Batavia Awal Abad XX. Jakarta: Komunitas Bambu. 2004.

Chambert-Loir, Henri (red.). Ziarah dan Wali di Dunia Islam. Jakarta: Serambi. 2007.

Couperus, Louis. Oostwaarts. Amsterdam/Antwerpen: L.J. Veen. 1992 [cetakan pertama 1924]

Dijk, Kees van. “Sarung, jubah, dan celana: Penampilan sebagai sarana pembedaan dan diskriminasi" dalam Outward Appearances, Henk Schulte Nordholt (red.), 57-120. terjm. Yogyakarta: LKIS. 2005.

Encyclopaedie van Nederlandsch-Indië. Vol. 1. Gravenhage: Nijhoff. 1917.

Graaf de, H.J dan TH. Pigeaud. Kerajaan Islam Pertama di Jawa: Tinjauan Sejarah Politik Abad XV dan XVI. Cetakan keempat. Jakarta: Grafiti. 2001.

Gouda, Frances. Dutch Culture Overseas: Praktik Kolonial di Hindia-Belanda 1900-1942. Terjm. Jakarta: Serambi. 2007.

Haks, Leo (red.), Indonesia: 500 Early Postcards. Singapore: Archipelago Press. 2004.

Hidayat, Komaruddin (red.). Menjadi Indonesia: 13 Abad Eksistensi Islam di Bumi Nusantara. Jakarta: Mizan. 2006.

Hisyam, Mohammad. "Potret Penghulu dalam Naskah: Sebuah Pengalaman Penelitian", dalam Jurnal Wacana, 125-33. Vol. 7 No. 2. Depok: FIB UI. 2005.

Kinloch, Charles Walter. Rambles in Java and The Straits in 1852. Singapore: Oxford University Press. 1987. [cetakan pertama 1853].

Lombard, Denys. Nusa Jawa: Silang Budaya, Warisan-Warisan Kerajaan Konsentris. Jakarta: Gramedia Pustaka Utama. 1996.

Maurik, Justus Van. Indrukken van een totok: Indische typen en schetsen. Amsterdam: 
Van Hoeve. 1897.

Olivier Jz, J. Tafereelen en merkwaardigheden uit Oost Indië. Leiden: KITLV. 2001. [cetakan pertama 1836, 1838].

Ponder, H.W. Java Pageant: Impressions of the 1930's. Singapore: Oxford University Press. 1989. [cetakan pertama 1934].

Ponder, H.W. Javanese Panorama: More impressions of the 1930's. Singapore:Oxford University Press. 1990. [cetakan pertama 1942].

Poortenaar, Jan. An artist in Java and other Islands of Indonesia. Singapore: Oxford University Press. 1989. [cetakan pertama 1928].

Said, Edward. Orientalism. New York: Verso. 1991.

Scidmore, E.R. Java The Garden of the East. Singapura: Oxford University Press. 1984. [cetakan pertama 1897].

Steenbrink, Karel. Beberapa Aspek tentang Islam di Indonesia Abad ke-19. Jakarta: Bulan Bintang. 1984.

Steenbrink, Karel. Kawan dalam Pertikaian: Kaum Kolonial Belanda dan Islam di Indonesia (1596-1942), Bandung: Mizan. 1995.

Suminto, Aqib. Politik Islam Hindia Belanda. Jakarta: LP3ES. 1985.

Tokugawa, Marquis. Journeys to Java. Diterjemahkan oleh M. Iguchi. Bandung: ITB Press. 2004.

Vredenberg, J. “The Haddj Some of its features and functions in Indonesia” dalam BKI 118. Leiden: KITLV. 1962. 91-154.

Wit, Augusta de. Java: Facts and Fancies. Singapura: Oxford University Press. 1987. [cetakan pertama 1905]. 